\title{
Intentionality, Conceptual Content, and Emotions
}

\author{
Intencionalidade, Conteúdo Conceitual e Emoções
}

LÉO PERUZZO JÚNIOR ${ }^{a}$

\begin{abstract}
The present study aims at supporting the argument that emotions, unlike a physicalistic interpretation, cannot be reduced to the conceptual elements used in the communication or exteriorization process. The subject is based on two hypotheses: the first is that the relation between the issuance of an emotive content (emotion) and a possible mental representation presents a linguistic nature. In general terms, this means that an emotion, or the psychological content associated with it is based on the plot of other concepts. The second hypothesis is that it is not possible to refer to emotions without considering cognition from a semantic problem and, consequently, in the refusal of a realistic or antirealistic posture in relation to the way the phenomena - internal and/or external to our consciousness - are referred. Thus, a conceptual model to understand emotions would be essential to settle the problem associated with ordinary language, realism, and the computational tendencies that comprehend the mental content in strictly syntactic terms.
\end{abstract}

Keywords: Intentionality. Conceptual content. Emotions. Language.

\section{Resumo}

O argumento que pretendemos sustentar neste artigo é que as emoções, diferentemente de uma interpretação fisicalista, não são redutíveis aos elementos conceituais utilizados no processo de comunicação ou exteriorização. Esta questão está alicerçada por duas hipóteses: a primeira, de que a relação entre a emissão de um conteúdo emotivo (emoção) e uma possível representação mental é de caráter linguístico. Isso significa, em termos gerais, que uma emoção, ou o conteúdo psicológico está associado, ou alicerça-se sobre a trama de outros conceitos. A segunda hipótese é de que não é possível fazermos referência às emoções se não tomarmos a cognição a partir de um problema semântico e, consequentemente, na rejeição de uma postura realista ou antirrealista acerca do modo como nos referirmos aos fenômenos internos e/ou externos à nossa consciência. Assim, um modelo conceitual para compreensão das emoções seria imprescindível para redimir o problema associado à linguagem ordinária, ao realismo e

\footnotetext{
a Pontifícia Universidade Católica do Paraná (PUCPR), Curitiba, PR, Brasil. Doutor em Filosofia, email: leoperuzzo@hotmail.com
} 
às tendências computacionais que compreendem o conteúdo mental em termos estritamente sintáticos.

Palavras-chave: Intencionalidade. Conteúdo conceitual. Emoções. Linguagem.

\section{Introduction}

Speaking repairs. The only coherent attitude based on non-signification would be silence, if silence, in turn, had no meaning. A perfect absurdity tries to be mute... (Albert Camus, The Rebel).

Philosophical semantics [Frege, Russell e Wittgenstein] has put hermeneutics in exile, a type of parenthesis responsible for determining the formulation of judgments beneath a subjective process. The classicism of the past and the etymological/philological controversy are overcome. Therefore, the explanatory dimension of interpretation will not emerge from an intellectual resource, but from a literary style that merges with the philosophical curriculum. But, is it possible to exhaust the meaning and eliminate the inertia that reaches the thoughts? Or, as questioned by Fichte in Von der Sprachfähigkeit und dem Ursprung der Sprache, "how has men developed the idea of reciprocally communicate their thoughts by means of signs?" And, also, "how should men designate through sounds objects that are not characterized by sounds?" 1 This paper aims at, on the one hand, rethink how the Conceptual content justification is part of the human experience and, on the other, show that the description of emotions cannot be assumed without considering a nonconceptual process ${ }^{2}$.

In his treatise Peri Hermeneias, Aristotle defined interpretation as "enunciation". The philosopher was referring to the mind operation that formulates true or false judgments about things. In this sense, Aristotle understands enunciation as an exposure of the truth of something as a judgment; the enunciation reaches the truth of something and incorporates it as a judgment" "Therefore, name is a significant

1 FICHTE, J. G. Da Capacidade Linguística e da origem da linguagem. São Paulo: Paulus, 2017. $\S 10 ; \S 35$.

2 Cf. GARETH, E. The Varieties of Reference. Ed. John McDowell. Oxford: Oxford University Press, 1982.

3 Cf. ARISTÓTELES. Da Interpretação. São Paulo: UNESP, 2013. 
sound by convention without indication of time, and none of its parts is separately significant". The result is the postulation that truth is correspondence, and saying is "judgment", as the very truth of happening becomes the static truth of principles and judgments.

A tradition of "hermeneuts" is based on the perspective of this observation. Some are driven by a metaphysical craving, others dissected by the literary exegesis. The binomial interpretation/understanding is inaugurated on the architecture of the Aristotelian legacy. The nudity of language seems to preserve all anti-essentialist efforts in the manifestation of meaning, creating a gap between perceptive experience and Conceptual-content. At the same time, a mirror image of this meaning becomes distant from the cognitive processes that support understanding. Retreat and approximation may be observed in this trench, as well a fight against an enemy that should not be killed. Killing it means a suicide, a reduction of the primacy of our understanding to an appeasement that cannot be found.

But, in practical terms, why does understanding the meaning of a speech based on the language manifests a particular locus that situates both the author and the interpreter in distinct cognitive horizons? Or, in other words, would our emotional content be finer than the concepts available? These questions, and a number of others, just reveal the apparent psychologization of the concepts used to refer to the content of emotions; as affirmed by Meunier (2017, p. 344), conceptual models allowed the expression of content in general

conceptual models share similar purposes with the other types of models. They are also mediators but they are used mainly for understanding, discovering, justifying, and communicating the research problem and solution explored in the scientific enquiry. They are not always expressed in natural language for they may take various other semiotic forms such as pictures, graphs, or films, all of which have their own ways of expressing conceptual structures. 


\section{From the dichotomy Sense/Understanding to the Cognition Problem}

Despite a series of objections, it would not be trivial to accept that the meaning is related to the projections and intents of the listeners. In other words, it would be the same as taking thought and speech as complementary functions, that is, the speech expressing the thought is inversely proportional to the argument that the thought fits into the linguistic resource. An extremely interesting metaphor regarding the subject [traditionally unaccepted by some individuals, especially within the scope of ordinary language philosophy — Davidson, Searle, Austin, among others] is that of the "analytic tradition languages"4. In this metaphor, the validity of the linguistic architecture, conceptual harmony, and argumentative performativity would be expanded only within the formalism that is not reached by certain natural languages. For this reason, the analytic tradition metaphilosophical dilemma reveals not only a mastery over the nature of signs, but particularly over the very perplexities of the cognition process and metaphysical craving of the linguistic/scientific realism ${ }^{4}$ that followed the Kantian philosophy.

The previous subject makes sense when, for example, the statement by Schleiermacher is taken into account, that is, "every act of understanding is the inversion of an act of speech by virtue of which the thought at the base of the speech should be brought to consciousness" 5 . Its response seems to receive a particular treatment when, on the one hand, the hermeneutic problem involving language is situated and, on the other, the human horizon and the historical penetration of the context into the text are observed. In this process, Schleiermacher points out that the interpretation mandatorily requires a linguistic and historical understanding. The interpreter maintains a process of alterity with the global framework of language, as people are far away from thinking the same things under the same words. The boundaries of our grammar are mixed with the shades of our own understanding. For

\footnotetext{
${ }^{4}$ Cf. DUMMETT, M. The Origins of Analytic Philosophy. London: Duckworth, 1993.

${ }^{5}$ SCHLEIERMACHER, F. Hermeneutik und Kritik. FRANK, M. (Org.). Herméneutique. Paris: Labor \& Fides, 1997. p. 101.
} 
this reason, a general theory of understanding would appease the narrow, doctrinal work carried out by the philological exegesis.

\begin{abstract}
The different levels of significability depend on the language status. No sufficient differences are observed in some of them; likewise, the duplicity of expressions is not there yet; upon these, the higher significability is based on. On others, no differences are found, but the use of the original unit is not lost yet. Therefore, a clear consciousness of the different processes and their known foundations may be observed here. In others, all oppositions are formed, but the original identity is lost. Therefore, expressions descending from those emerge here, but these are taken as a vain stratagem used as such ${ }^{6}$.
\end{abstract}

Therefore, significability is an act of speech brought to consciousness. It operates as type of condition ${ }^{7}$, being responsible for uncovering the bitterness and emptiness of the multiple faces of interpretation. It is like a sea-going fisherman: his goal is fishing, but he does not know which species of fish will be caught. As he collects his fishing nets, he effectively knows what he could found. The very multiplicity is the very obstacle brought to thought. For this reason, cognition occurs to the extent that grammar finds a certain order, a certain path of rationality (PERUZZO, 2018). However, all possible crossroads that the concepts may assume remain preserved around it, that is, its own characteristic indetermination, although comprehending all conditions of possibilities.

The emphasis on the binomial interpretation/understanding reveals not only the paradox reported by Schleiermacher between author/interpreter, on the contrary, it shows how the paradox conceptual/non-conceptual experience allows the placement of the characteristic virtuosity of language in the composition of our knowledge regarding the world. Perhaps this aspect, not dissociated from a series of others, is

\footnotetext{
${ }^{6}$ SCHLEIERMACHER, F. Hermenêutica: arte e técnica de interpretação. Petrópolis: Vozes, 2015, p. 84.

${ }^{7}$ The dichotomy content/experience, initially introduced by Sellars in his essay Empiricism and the Philosophy of Mind in 1956, and later rescued by McDowell in Mind and World (1994), reinforces the assumption that although reality does not depend on our thought, it should not be imagined as a domain outside the conceptual sphere. On the other hand, taking the Given/Condition only as what is imposed by coercion, or vice-versa, reinforces the argument that the conceptual content plays a secondary role in relation to the way things are. According to McDowell, the content of a judgment should be thought as a conceptual content, as "things are as such, and such way is, if we are not deluded, an aspect of the general disposition of the world: it is the way things are. Thus, the idea of conceptually structured receptivity operations allows an approach to experience as openness to the general disposition of reality. The experience allows the very general disposition of reality to exert a rational influence over what an individual thinks" (McDOWELL, J. Mind and World. Aparecida: Idéias \& Letras, 2005, p.63).
} 
presented as a central element in debates that insist on a distance between language, on the one hand, and world, on the other. Presumably, a significant part of the tradition - except for some realists such as Putnam $(1990)^{8}$ and Bunge $(2017)^{9}$ preferred to reject the dissociative argument between linguistic signs, cognition, and world. But could mere events of the world provide empirical content to our thoughts? Should experience act as a court over our ideas? And, yet, how do our emotions "fit in" the worldly events or phenomena that they intend to describe?

Materialist arguments (Place, 2002; Smart, 1959; 1978) to answer to the questions above are, in general, reductionists. Naturally, this is due to two reasons: firstly, for indirectly and mistakenly assuming an anti-realistic position in which the mental content is reducible to the very instantiation of the brain processes; and secondly, not less confusing, for situating the cognition plane in a sphere separated from the semantic plane. According to Place, for example, a number of aspects of the human experience or behavior could be treated non-dualistically. But, why would such argument be practicable when considering the analysis of emotions?

Place (2002) recognizes that there are uses of mental concepts that are tied to a strictly mentalist vocabulary, hindering the development of an appropriate image on the "inner side". Expressions with no required link between subject and predicate do not require the ontological reference of an entity to determine the actual value of the proposition. Consequently, a proposition $x$ and a proposition $y$ do not require distinct references to be true. On the contrary, as in the example used by Place (2002), a large soft-textured semitransparent mass suspended in the atmosphere consists in a reality of tiny particles of water. In other words, the "cloud" and the "mass of particles" mean distinct elements, but do not refer to different ontological entities.

Therefore, the association of mental content to distinct categories is not only an ontological error, but a semantic, dualistic inaccuracy based on the assumption that there are psychological categories that develop in a distinct way from other events. This argument, previously presented by Professor Griffiths in the work What Emotions Really Are: the problem of Psychological Categories, evidences the mythological tone

\footnotetext{
8 PUTNAM, H. Realism with a human face. Cambridge: Cambridge University Press, 1990.

${ }^{9}$ BUNGE, M. O realismo Científico de Mario Bunge. Interview with Léo Peruzzo Júnior. Revista de Filosofia Aurora, v. 29, n. 46, p. 353-361, jan./abr. 2017.
} 
involving the theme and, in this sense, the author points out that affective programs are only adaptive responses to events presenting a particular ecological significance to the organism. In this same sense, Griffiths (2008) steps back from cognitivists and neoJameasians by affirming that emotions should not be conceived as internal states or processes in which the environment is limited to providing stimuli and receiving actions. On the contrary, a perspective situated over cognition includes the perception that it is dynamically shaped by the context in which the cognitive episode occurs. This context changes with time, sometimes as a consequence of the very cognitive activity.

\title{
From Conceptual content to cognition
}

In Mind and World, the theory of McDowell would suggest that it is necessary to understand semantic facts as part of our practices rather than assuming them as links to the given world and indifferent to the conceptual practices in use ${ }^{10}$. This means that considering the experience independently of a conceptualized practice may be a mistake, as it is not possible to know whether these same concepts encompass the reality as it is in fact or as it should be. As pointed out by McDowell, the Kantian proposition regarding the unknowability of the world in itself was presented as the destination of the hermeneutic tradition. Therefore, any linguistic or scientific protocol contains the danger of misunderstanding, strangeness, and formal limit when intending to be a perspicuous representation of the world.

\begin{abstract}
If restricted to the perspective of the very experience, the image which I have been suggesting is precisely observed in Kant: a conception in which reality is not located outside the boundaries that surround the conceptual sphere. It is no coincidence that I can express in Kantian terms what I am advising. The fact that experience involves receptivity ensures the required coercion coming from outside thoughts and judgments. However, considering that the deliveries of receptivity already use capacities belonging to spontaneity, it is possible to coherently assume that coercion is rational. This is how our image avoids the Condition trap (MCDOWELL, 2005, p. 79).
\end{abstract}

True to the Kantian project, McDowell affirms that the natural should not be conceived from a kind of contrast between its mode of intelligibility and the intelligibility belonging to the inhabitants of the space of reason. In other words, this

${ }^{10} \mathrm{Cf}$. McDOWELL, J. Mente e Mundo. Aparecida: Ideias \& Letras, 2005. 
means postulating the possibility of a symmetry between the perceived experience and its conceptualization if, as intended by the author, "symmetry" does not mean the traditional parallelism of modern philosophy. For this reason, all content is conceptual, as it is not possible to exist anything in the experience that may be disconnected from the faculty of spontaneity: "The conceptual sphere does not exclude the world that is experienced. In other words, what is experienced is not external to the realm of the type of intelligibility of the meaning" (McDOWELL, 2005, p. 109). Therefore, the dualism of rule and nature would be nothing more than platonically conceived phantasmagoria.

But, could non-conceptual content be integrated to experiences if it was not conceptual from its inception? Or, would perceptive content be possible for beings presenting language and beings presenting no language? According to McDowell, contents of experiences cannot be considered independently of the concepts available. For example, the perception of the blue or red colors is already present in the very experience that describes such possibility. In this case, the use of the term "conceptual" is the way through which appearances may become judgments regarding the objective reality. In this sense, in the article "Non-Cognitivism and RuleFollowing", McDowell affirms, in Wittgensteinian style, that it is not possible to characterize the practice - or behavior of an individual participating in it - without the use of normative notions such as rules, customs, institutions, among others. Among other reasons, this impossibility of characterization is due to the fact that it is not possible to think an action as a process apart from language and the whole web of elements that are part of the understanding and behavior of an individual (PERUZZO, 2018).

Regarding the second point, that is, whether animals would have access to a Conceptual content regardless of a linguistic character, McDowell appeals to a particular position full of encumbrances: “[...] It is possible to say that we have what other animals have, that is, perceptive sensitivity to characteristics of our environment; however, we present it in a special way. Our perceptive sensitivity to our environment is received within the faculty of spontaneity, and this is what differs us from them" (McDOWELL, 2005, p. 102). Therefore, the conceptual performance is mitigated by the act of sharing perception and memory with other animals, making 
the Myth of the Given an unlikely position. Sharing the position of Sellars in his work Empiricism and the Philosophy of Mind, McDowell considers that Givenness, in the sense of the Myth, would be an availability of cognition for subjects whose apprehension of what is supposedly Given to them would not depend on the capacities required for such cognition. Now, having something given would be taking something to know without the need to have such capabilities to make possible to get to know them.

At least two fundamental objections are presented to the questions raised by McDowell. The first one, of normative nature, is that the argument that "freedom of spontaneity should be a kind of exemption from nature, something that allows people to rise above it, and not our way of living an animal life" (McDOWELL, 2005, p. 102) explains the impossibility of nonhuman beings present perceptive content, yet nonconceptual and, even so, get to know the world. If the argument of McDowell is correct, it would be primarily necessary to understand how such conceptual content is possible, as without it the access to experiences would not be possible either. Perceptive delusions or hallucinations, for example, would depend on a conceptual motto or would, independently, be sources of knowledge? If there is no gap between the way things seem to be and how things might be, then the notion of appearance is not only essentially disjunctive but ignored.

Not dissociated from the first, the second objection to McDowell presents an epistemic character. The author applies "conceptual" by associating it to the term "being aware of", as all perceptive content is taken as conscious. Following most philosophers, McDowell makes a leap between the hypothesis that all non-conceptual content makes knowledge about something possible, as well as the very passivity of the agent in the reception and organization of the experience. Therefore, the justification of the faculty of perception as a criterion for differentiation or surpassing between human beings and nonhuman animals represents one more difficulty. Similarly, to the Kantian architecture of Critique of Practical Reason, as follows, McDowell overrides truisms by pointing out men as rational creatures endowed with the faculty of spontaneity. Kant affirms (2002, p.141): "In all creation, all that is desired and upon which any power is exercised, may also be used just as a means; only men, and every rational creature with them, represent an end in itself". Or: "Respect will only have to do with people, never with things. These may arouse inclinations in 
us and, regarding animals (for example, horses, dogs, etc.), even love or fear, such as the sea, a volcano, a prey animal, but never respect” (KANT, 2002, p. 124).

\section{Intentionality, Consciousness, and Emotions}

An important point to be discussed, overlooked by McDowell, is the belief that we are immediately aware of what is experienced, that is, that the information processing occurs simultaneously with the cognition process. However, experiments about the time of conscious perception revealed that the input consciousness occurs at least 200 milliseconds (ms) after the stimuli reach the cortical surface (VELMANS, 2010). Other studies with electrode stimulation pointed out, for example, that somatosensory cortex stimulation only occurs $200 \mathrm{~ms}$ after the tactile stimuli (LIBET et al., 1979 apud VELMANS, 2010). The conclusion is that the perceptive content processing takes time to produce neural conditions to support consciousness. The lapse between the input of information and the awareness about such content would be compensated by the brain when processing the representations built by it.

Therefore, the brain records the arrival time of the tactile stimulus with a "time marker". However, it remains unknown how such time lapse is filled by other structures or how the construction of representations actually occurs without a symmetrically direct content. In the same study, according to Velmans (2010), microelectrode stimulation applied directly to cortical areas, such as the medial lemniscus (ML), did not produce these time markers. The contrast between the subjective time of the stimuli, with and without such markers, revealed that tactile stimuli applied $100 \mathrm{~ms}$ after those cortical ML appeared subjectively, showing that the former would not be late. Therefore, the lapse between the stimuli processing and the awareness of them would reveal, on the one hand, that the non-conceptual content also integrates the list of tools through which we "understand" the world, and on the other, that there is a misconception when conscious experiences are associated to any and all cognitive processing. Therefore, would it be possible to accept the argument that the content of emotions would be reducible to the conceptual content or, on the contrary, that such processes occur independently of a non-conscious physicalchemical movement? 
The question above reveals a vastness of other questions: what is the content of an emotion? How does the semantics of a term determine its content? Is there a demarcation between the content of an emotion and a possible non-conceptual experience? How do emotions "fit in" with worldly events? Thus, these problems reveal one of the arguments of Evans in his posthumous work The V arieties of Reference, in which the information produced by perceptive systems are non-conceptual. This information is initially perceived as unconscious, but it becomes conscious when it acts as an input to a system of thoughts, application of concepts, and reasoning. In this case, conscious experiences would be associated to certain forms of thoughts but implying no compromise between the very consciousness and brain activities.

Therefore, a direct implication to the scenario of this debate consists in the existence of a causality between "being conscious" and the "emotive content" that should be associated to it. If consciousness is a qualitative problem that cannot be reduced to a normative instrument of observation, linguistic for example, so it is unlikely that the cognitive content may be thought only in "conceptual" terms. In other words, it means that the intensity of the phenomena perceived by the agent is not restricted to the semantic capacity of its describability, except if there was a limited number of basic emotions and the corresponding conceptual categories (PERUZZO, 2016).

The reason for the mentioned argument is simple. Firstly, because emotions may be perceived as dynamic systems, that is, they cannot be described as a regular or causal phenomenon. Therefore, it means that they are not merely mental phenomena correlated with the conceptual or linguistic content; on the contrary, they consist in an inseparable movement linked to social practices. For example, the dichotomy imposed by Damásio (2000, p. 55) between emotions and consciousness, as well as the argument that although animals present emotions, human beings are the only species that are able to link them to ideas, values, principles, or complex judgments, do not respond to the problem of mental causation. In other words, affirming that emotions are dynamic systems means taking them not as properties of consciousness or qualities of a neurophysiological process, but as a conceptual content that is inseparable from internal (neurophysiological and mental processes) and external (semantics of the terms that describe such states) elements. 
Secondly, contradicting the arguments presented by Giovanna Colombetti in From affect programs to dynamical discrete emoticons, when referring to the "Dynamical Cognitive Science", the use of dynamic conceptual tools for description and prediction purposes does not explain the problem of the normative reducibility of the content of emotions. This thesis seems to corroborate negatively with the arguments, as it assumes that interactions are very dense parts, making it impossible to track how each individual part contributes to the overall behavior of the system. Neurochemical distinctions between affective and cognitive variants may only be interpreted when the conceptual framework that would inevitably need to "fit" into the description is considered. A possible isomorphism between the neurophysiological or mental state (where emotions occur) and the term used for its description represents an argument that is distant from our position, as they only corroborate to a reducible image of the very content of emotions.

\section{Final considerations}

In Conceptual terms, the describability of emotions is presented as an essential problem in both philosophy and cognitive sciences. In general, the states of emotions appear associated with a neurophysiological image of the cognitive processes that would be responsible for their dynamics. As previously pointed out by Velmans (1996), the dissociation of the Conceptual content of Emotions, taking them as a set of properties resulting from such states, does not explain the cognition process movement. On the contrary, it just revitalizes a classic argument that insists in the separation of consciousness from the properties that would be caused by such structure.

Therefore, an emotion is a dynamic system, as is should comprehend both the consciousness about the content and the meaning linked to it. In this sense, emotions are not caused - by the brain or a mental state - as the very causation requires a conceptual content. Emotions are the very brain and the very mental state. Refusing an ontology of emotions means putting them back in the grammar of common sense, a locus that preserves the possibility of understanding the intensity of the phenomena and the "density" of the world. 
Finally, three points demand consideration in the assessment of content of emotions, and consequently, how they behave in ordinary life. The first one, mentioned above, is the causation of emotions, that is, whether priority is given to the internal (brain) or external (social practices) part and the extent of their correlation. Seemingly, both solutions are incongruous, as such argument would lead to a requirement of a "me" to promote decisions when the incited movement is conscious. When they are unconsciously incited, the possibility of their description in causal terms becomes even more distant.

The second question to be responded consists in the third-person emotions argument. The adoption of a type of behaviorism for its description is also an illusion, except upon acceptance of the thesis that we know what is going on with others because we recognize its content based on our practices. Thus, for example, contemporary discussions regarding computational attempts to simulate the human cognitive capacity insist in a "basic misconception" in their analogy processes: the definition by a computer has its specifications in formal terms, that is, abstract symbols (zeros and ones). These binary symbols do not present meanings or semantic content. In other words, computer software may be defined in purely formal or syntactic terms, consisting in electronic systems capable of manipulating symbols very quickly. For this reason, in order for computer systems to be identical to the human mind, they should have the same causal powers presented by the human brain, especially in relation to the dynamic ability to operate with emotions and a semantic language capable of encompassing the plurality of cultural, social, moral, and poetic combinations, among others.

Finally, the problem of realism represents a little explored element - replete with incongruities - in the literature about Conceptual content of Emotions. If the theoretical statements refer to entities that are external to theories, or even committing with unobservable entities, would an external world operating as the court of propositions be required when approaching the content of emotions? Differing from the realists, a commitment with a world consisting of autonomous properties would not be required when approaching emotions. Thus, if force, inertia, and gravity are not mental constructs, but, as realists think, really existing entities as they reveal the causal structure of the world, emotions should be recognized as dynamic processes 
of reasoning and decision situated beyond an external/internal or physical/mental reductionism.

\section{References}

BERMÚDEZ, J. L. The Notion of a Nonconceptual Point of View. In: BERMÚDEZ, J. L.; MARCEL, A. J.; Eilan, N. (Ed.). The Body and the Self. Cambridge/MA: MIT Press. 1995a. p. 153-173.

COLOMBETTI, G. From affect programs to dynamical discrete emoticons. Philosophical Psychology, v. 22, n. 4, p. 407-425, 2009.

DAMÁSIO, A. O Mistério da consciência: do corpo e das emoções ao conhecimento em si. São Paulo: Companhia das Letras, 2000.

EVANS, G. The Varieties of Reference. Oxford: Oxford University Press, 1982.

GRIFFTHIS, P. Griffiths, na obra What Emotions Really Are: the problem of Pshychological Categories. Chicago: Chicago University Press, 1997.

GRIFFITHS, P. Emotions in the wild: The situated perspective on emotion. In: ROBBINS, P.; AYEDEDE, M. (Eds.). Cambridge Handbook of Situated Cognition. Cambridge: Cambridge University Press, 2008.

KANT, I. Crítica da Razão Prática. São Paulo: Martins Fontes, 2002.

McDOWELL, J. Sellars on Perceptual Experience. The Journal of Philosophy, New York, v. 95, n. 9, p. 431-450, sep. 1998.

McDOWELL, J. Mente e Mundo. Aparecida: Ideias \& Letras, 2005.

MEUNIER, J.-G. "Theories and Models: Realism and Objectivity in Cognitive Science". In: AGAZZI, E. (Ed.). Varieties of Scientific Realism. Objectivity and Truth in Science. Germany: Springer, 2017.

PERUZZO JÚNIOR, L. As antinomias Metaéticas entre cegos e não-cegos e o problema do realismo moral. Veritas, Porto Alegre, v. 61, n. 1, p. 62-74, 2016.

PERUZZO JÚNIOR, L. Realidade, Linguagem e Metaética em Wittgenstein. Curitiba: PUCPRESS, 2018.

PLACE, U. T. Is consciouciousness a brain process? In: LYON, W. (Org). Modern philosophy of mind. London: Ed. Everyman, 2002.

SELLARS, W. Science and Metaphysics: Variations on Kantian Themes. Atascadero: Ridgeview Publishing Co., 1992.

SELLARS, W. Empiricism and the Philosophy of Mind. Introduction by Richard Rorty, and a study guide by Robert Brandom. Cambridge, Mass.: Harvard University Press, 1997. 
SMART, J. J. C. Sensations and brain processes. The Philosophical Review, v. 68, n. 2, p. 141 156, 1959a. Disponível em: <http://www.jstor.org/stable/2182164>. Acesso em: 24 mai. 2019.

SMART, J. J. C. The content of physicalism. The Philosophical Quarterly, v. 28, n. 113, p. 339341, 1978. Disponível em: <http://www.jstor.org/stable/2219085>. Acesso em: 24 mai. 2019.

VELMANS, M. Consciousness and the "causal paradox". Behavioral and Brain Sciences, v. 19, n. 3, p. 537-542, 1996.

VELMANS, M. What Perception Becomes Conscious. British Journal of Psychology, v. 90, n. 4, p. $543-566,2010$.

WITTGENSTEIN, L. Investigações Filosóficas. Lisboa: Calouste Gulbenkian, 1995.

RECEBIDO: 08/15/2019

RECEBIDO: $15 / 08 / 2019$

APROVADO: $10 / 25 / 2019$

APROVADO: $25 / 10 / 2019$ 